\title{
Fonctions spécifiques des techniques de pêche dans une production halieutique
}

Aliette Geistdoerfer

\section{(2) OpenEdition \\ Journals}

Édition électronique

URL : https://journals.openedition.org/tc/1026

DOI : $10.4000 /$ tc. 1026

ISSN : 1952-420X

Éditeur

Éditions de l'EHESS

Édition imprimée

Date de publication : 1 septembre 1983

ISSN : 0248-6016

Référence électronique

Aliette Geistdoerfer, «Fonctions spécifiques des techniques de pêche dans une production

halieutique », Techniques \& Culture [En ligne], 2 | 1983, mis en ligne le 26 janvier 2006, consulté le 29

septembre 2022. URL : http://journals.openedition.org/tc/1026 ; DOI : https://doi.org/10.4000/tc.1026

Ce document a été généré automatiquement le 29 septembre 2022.

Tous droits réservés 
Fonctions spécifiques des techniques de pêche dans une production halieutique

Aliette Geistdoerfer 